\title{
How to Teach Spanish as a Second Language Based on a Textual Progression Method
}

\author{
Cristina del Moral Barrigüete \\ Faculty of Education and Humanities of Melilla \\ University of Granada
}

Received: 28 March 2009 / Accepted: 12 June 2009

ISSN: $1697-7467$

\begin{abstract}
In this paper the basic characteristics of a new approach based on a textual progression are discussed. Textual progression essentially encompasses a gradation criterion based on thematic and pragmatic relevancy, the development of a communicative competence adapted to the situation, the context under consideration of different communicative intentions and types of text, as well as different themes, related to the learning needs of the students in question. A written text, -complex and finished, that includes all kinds of linguistic materials- is one that inspires the reader to think about the different linguistic, cultural or other aspects that it brings to light. It will be the pupil himself, as an autonomous being, who determines his own grammatical advance. As a practical example, the third part of the first lesson of Spanish as a foreign language at level A2 ${ }^{1}$ is shown below, following a new methodological approach called Collage Method: The Teaching of a Foreign Language based on Strategies of Reading Comprehension of Texts from the Work Life. ${ }^{2}$ In this activity, specifically, we deal with an informative text. Our main goal is comprehension, in accordance with a few objectives and its textual characteristics, with the consequent outline of the linguistic materials tailored to every student's individual needs.
\end{abstract}

Key words: textual progression, autonomy, strategies, reading comprehension.

Cómo enseñar español como segunda lengua basándose en un método de progresión textual

RESUMEN: En este artículo se intenta explicar las características básicas de un nuevo enfoque basado en una progresión textual. La progresión textual se basa fundamentalmente en un criterio de gradación sobre una base de relevancia temática y pragmática, el desarrollo de una competencia comunicativa adecuada a la situación, el contexto bajo consideración de diferentes intenciones comunicativas y tipos de texto, así como diferentes temáticas, relacionadas con las necesidades de aprendizaje de los estudiantes en cuestión. Un texto escrito, -complejo y completo, que incluye todo tipo de material lingüístico- es el que impulsará a plantear diferentes aspectos lingüísticos, culturales, etc. que puedan surgir de él. Será el propio alumno, como ser autónomo, el que determine su progresión gramatical.

1. A2 (Basic User) according to the terminology of Council of Europe (2001). Common European Framework of Reference for Languages Learning, Teaching, Assessment.

2. This new approach has been taught successfully to students of German as a third foreign language for more than seven years in the Faculty of Translation and Interpretation in the University of Granada, as part of an Innovation Teaching Project heading by Möller Runge, J. (Phd.) 
Como ejemplo práctico, se muestra a continuación la tercera parte de una primera lección de español como lengua extranjera para un usuario básico (A2), y siguiendo un nuevo enfoque metodológico llamado "Método Collage: Enseñanza de una lengua extranjera basada en estrategias de comprensión lectora de textos procedentes de la vida laboral". En esta actividad, en concreto, nos enfrentamos a un texto informativo, y la finalidad última es la comprensión del mismo, de acuerdo a unos objetivos, sus características textuales, con la consiguiente esquematización del material lingüístico que aporte a cada estudiante, de manera individual.

Palabras clave: progresión textual, autonomía, estrategias, comprensión lectora.

\section{INTRODUCTION}

We cannot deny that the real needs our students have today when learning a second language have to do with personal aspects as well as professional ones. Currently, the Spanish language is studied for more reasons than just going to the supermarket or going out to a party ("fiesta"), in other words, to meet personal needs. Every day, more and more young people approach learning Spanish with professional aims, as they want to secure a future with bigger and better work opportunities, causing Spain and Latin-America to become possible places of work. In this way, Spanish with a specific purpose has made a significant impact in the classroom. We can study specific subjects for specific professions, such as Spanish for business, Spanish for medicine, Spanish for tourism, and so on.

It is clear that language-teaching methodology has been changing over the years. For a long time, we have been using behavioral methods such as the traditional, structuralist and audio-lingual methods, and then we used cognitive methods such as the communicative method or an approach based on tasks. The latest tendencies try to include all these methods and present an eclectic methodology, centered on the student and encouraging his independence.

In this paper, in which we present a section of a complete didactic unit for Spanish as a Second Language (2L), we have followed a new approach of teaching titled Collage. This method has all of the above characteristics and moreover they are treated in an innovative way, as we will see in the following pages.

\section{Characteristics of the collage method}

First of all, we must explain a basic concept for the comprehension of this method: textual progression (Möller, 2001). Textual progression is a new way of understanding how to teach a second language. It is based on a gradation criterion based on thematic and pragmatic relevance. It is important to stress that we only work with authentic, complex and complete texts. They include all kinds of linguistic and original ${ }^{3}$ materials because this method is not based on a grammatical progression, but on a thematic, pragmatic and textual progression.

3. By original, we mean that we have not altered the original text, in order to avoid any difficulties with grammatical structures. 
On the one hand, the selection of the texts is made according to the student's world knowledge, his Mother Language (ML) and his knowledge of other Second or Third Languages $(2 \mathrm{~L}, 3 \mathrm{~L})$. The selection is also in some way based on the texts with which we gradually work. On the other hand, it is the student who determines his progression, not only grammatically speaking, but also in a lexical way. Thus, the student determines his own grammatical and lexical advance, subtly guided by the texts. Nevertheless, the selection of the texts also determines all these aspects.

The starting point of the whole learning process is reading comprehension, and it will always be a written text that inspires the selection of all the other aspects: linguistic, cultural, and so on. But this is only the starting point - this is not a reading course because at the same time other skills are exercised: listening comprehension (with a video or CD), oral skills (conformed to the texts and other possible situations in the class) and writing activities to transfer passive knowledge into active knowledge. Lockhart suggests in relation to vocabulary that:

[...] written communication offers the student a situation that facilitates the transfer of passive vocabulary into active vocabulary. If the student rarely writes in the $2 \mathrm{~L}[\ldots]$ it is likely that he will transfer very little passive vocabulary into active vocabulary. (Lockhart, 1993:28)

In this new method of language teaching, we give importance to the development of a series of linguistic and extra linguistic competences, such as the ability to look for and consult reference works, and we promote intercultural competence. Students are guided toward an intellectual use of different reference works: using bilingual and monolingual dictionaries ${ }^{4}$, recognizing the importance of parallel texts, researching themes and texts on the Internet, using encyclopedias, studying different grammar systems with different approaches, etc.

Selbständige Arbeit seitens der Studierenden wird nicht nur durch das Selbststudium, sondern auch durch ein autonomieförderndes Unterrichtsverfahren bestärkt, das möglichst alle Lehrgegenstände erfasst und sich nicht auf den Sprachunterricht beschränkt. (Estelrich, 1998: 87).

In order to get our students to be autonomous:

Autonomy is to be seen in the exercise of a capacity for independent thought and action. (...) In formal learning contexts, the first step towards autonomy is conscious acceptance of responsibility for one's own learning (Little, 1997: 34).

The objective of the Collage teaching method is to develop a communicative competence according to the situation, or the context in relation to the different communicative intentions and types of texts. We need to be familiar with different textual principles, not only for spoken texts, but also for written texts.

4. We opted for a combined monolingual and bilingual learner dictionary to cater to individual reference preferences. 
Das bedeutet einerseits, dass man Texte verstehen und die Absichten des Senders interpretieren kann, und andererseits, dass man zweck-, adressaten-und textsortengerechte Texte produzieren kann. Ausserdem gehört dazu explizites Wissen über kommunikative Strukturen und Muster (z.B. Sprechakte, Sprachgebrauchsnormen und Textsorten) sowie Rezeptionsstrategien und deren Wirkung. (Hansen, 1998: 341)

Finally, we teach lexical competence with Collage by trying to avoid the equivalences $1=1$ (or direct translation). The student should develop certain learning techniques and strategies to incorporate new words into his lexicon in the $2 \mathrm{~L}$, organized in personal notebooks by lexical fields. In this way, he should pay special attention, for example, to the formation of words in Spanish to find the meaning or the concrete sense of the word in question. He is helped by his previous knowledge as well as his ML, and he makes comparisons and assimilations, thereby experimenting with the new language in a creative way. This is in line with Meara (2007: 29), who believes that:

[...] simulations can throw valuable light on the way we interpret the data generated in experiments with real subjects, and simulations can help us ask better research questions and design better research instruments to answer them.

\section{Characteristics of THe STUdents AND Learning ObJectives}

The group of students, to whom the activity is directed, has the following characteristics:

1. A homogeneous group of adults

2. Students with some knowledge of English

3. Students without prior knowledge of Spanish

4. Students who have very little time to reach a high level of linguistic competence

5. Students who wish to learn Spanish to gain another tool to compete in the job market, to increase their opportunities in the professional, economic, social or sociopolitical sphere, etc... ${ }^{5}$

Our goal is for our students to be able to apply -in the shortest time possible- the knowledge of the new language to complex communicative situations, considering the possible intercultural differences at every level (different behaviors, interpretations of reality, textual characteristics...).

We also hope that the students will have a command of the $2 \mathrm{~L}$ to be in possession of a great amount of information related to any aspect that may be of interest throughout life, and not only at everyday levels.

It is advisable that the group be homogeneous, that is, that they all share a common language, in our case English, whether it is the $2 \mathrm{~L}$ or ML. The influence of the ML in SLA (Second Language Acquisition) is a fact we cannot deny. However, we should try to make a

5. See "El español en el mundo", Annuary of Cervantes Institute (2004) 
rational use of the ML in the 2L class, using the ML as a work tool. Bachmann (1994), Hurtado (1994) and Valero (1996) have also discussed the integration of the ML from the beginning because they think that the student is more dependent on it during this stage. Thus, it is not necessary to force the student to speak in the new language from the beginning, but only when he feels ready to express himself in the $2 \mathrm{~L}^{6}$.

The main assumptions made in our research are:

1. The global component of discourse is the core aspect of the linguistic competence.

2. Increased global discourse competence has a positive effect on the overall communicative competence.

3. Overcoming the traditional teaching methods at schools through a context-based methodology improve classroom management and students' participation.

Consequently, the main objectives of this research are, on the one hand, to complete todays' second language teaching studies, which seem insufficient due to the lack of empirical studies within this field; and, on the other hand, to improve significantly the development of students' communicative competence through the systematic and planned work in class, as we believe in the key role of these strategies in the overall second language learning processes. So we offer an innovative methodology for Spanish as a second language teaching called Collage.

\section{Procedures of in-Class WORK With Collage}

We divide the structure of the class into two parts: what we have called "authentic reading," whose main objective is global comprehension of the text, and "analytic reading," whose basic factor is reflection on the new language. The idea is for the student to reflect independently on the new way of proceeding with his learning of Spanish, again encouraging his autonomy.

The teacher starts the classes by introducing the topic with several questions that will help the student reflect on the content of the text that he will read. (See figure 1.) In this case, we exploit the image that appears with the text. (See figure 2.) Recently, Nation has argued that:

This reading activity is an experience task because most of the knowledge needed to complete the task is already within the learner's experience. The language needed to do the task comes from the learner (it is their story; the ideas in the reading of the text come from the learner; and the organization of the text comes from the learner. (Nation, 2007: 33).

It is not important that we guarantee in an individual way the comprehension of all the possible questions that we ask and their corresponding answers. However, we should allow the

6. In the following activities, we can see the questions both in English and in Spanish. Progressively, we attempt to use the 2L (Spanish) more than the ML (English). 
student time to reflect, clarify, change his mind, and become aware on his own of what he is seeing and doing.

The first steps are the exploitation of the image and the reading of the title. At this point we try to activate the prior knowledge of the student, as with any reading activity (Solé, 1992).

We should remember that forming a hypothesis about the title is a strategy, among others, that will allow for a better confrontation with the text later. (See figure 3.) The novelty of this approach is that we consider the emitter, the possible receiver, the cultural function, the typology and structure of the text and the macrostructure. All of these things provide us a more complete understanding of the text, better preparing the student - with more real knowledge rather than hypothetical knowledge- for the confrontation with the text itself.

Afterwards, we have a first comparison of the different hypotheses in order to confirm or discard the first ideas that have been established about the text that they have not yet seen.

First of all, we present the text in audio form while the student reads along. The objective of this step is to allow the student to become familiar with the new sounds of the $2 \mathrm{~L}$ and to develop a first impression of the text. He is given total freedom in the way of approaching it, as he may follow the reading strategy that he considers appropriate for this first contact with the text.

We are still in the first phase of work with the text, which we have designated the "authentic reading" stage, whose fundamental goal is to understand the ideas necessary to comprehend the text. We establish a reading objective or objectives. To accomplish these, the current proposed exercises should be focused on those aspects of the text that the student can easily understand due to the relationship between external and internal factors in the text, such as the typological knowledge or knowledge related to the communicative intention of the text, the date and place of its publication, the topic, the author, etc. These factors should always be considered in conjunction with the student's world knowledge and intercultural or linguistic knowledge of this language or others. In no way do we expect the student to gain a total comprehension of the text.

We can now ask the student to do a first individual reading of the text without stopping (See figure 4.), or without dwelling on unknown words or confusing fragments, so that the student will value what he already knows instead of becoming frustrated with mistakes or fearing the unknown. Hulstijn, Hollander and Greidanus argue that:

Advanced L2 learners, [...], do not feel an urge to interrupt the flow of reading by investing considerable time and mental effort to infer or look up the meaning of unknown words. They will only do so when they perceive the word as relevant $[\ldots]$ or when alerted or even annoyed by the fact that the word keeps returning in the text. (1996: 335)

We establish a suitable time for reading, which, in this case, is four minutes - double that which a native speaker would require to read the same text in his ML. Then, we can ask for another brief reflection, this time about what has been read (first individually, and then with another student). We compare the conclusions with the previous expectations: verifying or discarding the previous hypotheses, as this phase involves an information exchange in pairs. 
This kind of group work (the exchange of opinions between partners) involves exchanging the students' constructive and creative ideas. Its objective is to offer new points of view or different strategies in order to ratify or discard hypotheses. We also supervise the work appropriately, favoring the autonomy of the student in his learning process.

We begin a new reading of the text, repeating several times, depending on its difficulty. The points of reflection are related to the subject, the intention, the structure, tone, presentation, etc., but we get closer and closer to discussing the content of the text.

We have already asked the student to look at the typographic aspects of the text because in this case it facilitates comprehension of its structure: dark gray color for city or country where the course takes place; bold for relevant and repeated information (contact addresses and telephones, price, dates of the courses, ages allowed to participate in the courses...); colon to introduce an explanation;...

Finally, we close this first phase of "authentic reading" by sharing ideas, with the purpose of verifying that the main reading objective has been accomplished. Most of the necessary changes and corrections have been made by the student, which he will find rewarding. The teacher's role is to guide the student's process of analysis, trying to direct his reflection on the $2 \mathrm{~L}$ without the student perceiving the guidance so that he believes that he has answered the questions about the text independently. The teacher asks questions and proposes hypotheses about the usage of the language but does not offer solutions (Cervero y Pichardo, 2000), encouraging experimentation with the new language.

We now begin the second part of our work, the "analytic reading," based on a textual progression. We encourage the student to think about everything he has already done, to analyze all those linguistic and extra linguistic aspects that he has recognized during his work with the text. The student systemizes the linguistic material in order to get closer to the form and function of the content of the text. The linguistic advance that he has made from the first reading to the last one is a schematization phase.

At this point, we help the student create personal notebooks in which he writes down all the information that could be useful (textual characteristics, grammar, phonetics, intercultural aspects, lexical fields, communicative intentions, procedures of working, etc.) On the blackboard we can make several columns containing this information ${ }^{7}$ and providing examples for each column, contextualizing each and every one of the expressions.

In short, this "analytic reading" creates the foundation for advance in the learning process, or the textual progression. Finally, we encourage the student to review what he has learned in class to reinforce the new knowledge of the language he is learning, in our case, Spanish. Dickinson offers (1997: 97) an interesting and organized way to proceed with a reflection on any concrete task, by asking oneself these questions:

7. We remind the reader that at this point only the information that students have detected from the text is included, not the whole language system. 
$\mathrm{G}=\mathrm{GOAL}$

What are the learning goals for this unit? What can I learn from this material?

$\mathrm{O}=$ OBJECTIVE

1) What are the immediate objectives of the task I am going to do?

2) Do I have any additional objectives of my own which I wish to work on by using this task?

$\mathrm{A}=\mathrm{ACT}$

How do I do the task? What is the best way of doing it?

$\mathrm{L}=\mathrm{LOOK}$

Look at your learning. Ask yourself:

1) Did I learn what I set out to learn? If not, why not?

2) What should I do now?

Am I satisfied with what I have learned?

Would it be useful to do the task again? Why?

Does this task suggest other objectives which I should pursue?

Note them.

Look at the way you did the task.

3) Did it work well, or is there a better way?

Were there any things I would do differently? Why? Note them.

\section{Conclusion}

The present study has attempted to clear up the most important aspects of using the "Collage Method". At any rate, we think that this teaching approach not only helps with learning, but also with acquisition (Krashen, 1977) of the language, which is its advantage, thanks to the following basic aspects of this approach:

a. The textual progression. As we use original, complete texts that have not been adapted, we do not expect total comprehension of the text from the beginning. Little by little, with each reading, the student will be able to understand more and more about the text he is reading, due to the analytic and reflection exercises he will do about the new language. He will also learn to set reading and reading comprehension goals, according to the type of text. The emitter, the intentionality, the possible receptor and, above all, the textual macrostructure itself will determine the minimum necessary degree of comprehension.

b. We will consider different types of texts and topics, thinking about which ones will be of greater interest to the students -according to the training needs of the group and related to their future professions. 
c. We encourage competence in reception of the text and in the systematic work with it as a starting point and base for future advance in language proficiency. There is common agreement that vocabularies are central and even a precondition to different areas of language proficiency such as reading and writing. Qian (2002) proved that vocabulary knowledge was instrumental to reading comprehension and predicted to some extent performance in this skill.

d. The student determines his own linguistic advance; however, in some way, the selection of the texts determines the contents, which is why the criteria of the selection are deciding factors in the student's development. But it is the student who decides -as an individual- what, when and how to make notes in his notebook. In this way, the student learns about his learning process and becomes acquainted with different kinds of strategies.

e. As we have pointed out in several exercises, the teacher plays an essential role in developing the student's independence. He should act as a guide, posing questions and hypotheses, but not answering all of the student's questions. Therefore, we introduce some procedures of working with the text. The teacher is always present, but with a different role than he has previously had.

f. Finally, we think that the use of ML helps with the acquisition of the $2 \mathrm{~L}$ because we should draw on everything the student knows, including his prior knowledge of the world, and we should incorporate this knowledge into his learning process. Therefore, we prefer the use of ML in the beginning of the learning process because it can facilitate comprehension, and in some cases, can be an intermediary for both languages. We can alternate both languages until, little by little, we only use the $2 \mathrm{~L}$.

\section{Bibliography}

Bachmann (1994). "La traducción como medio de adquisición del idioma" in J. de Agustín (eds.) Cuadernos de tiempo libre. Colección Expolingua. Traducción. Interpretación. Lenguaje, 13-26.

Cervero, $\mathrm{M}^{\mathrm{a}}$ J. y Pichardo, Fa . (2000). "Autonomía y estrategias de aprendizaje" Aprender y enseñar vocabulario. Madrid: Edelsa.

Dickinson, L. (1997). “The G.O.A.L. procedure for learner training” en MÜLLER-VERWEYEN, M. (Ed.). Neues Lernen, Selbstgesteuert, Autonom. 93-102.

Estelrich, P. (1998). "Deutsch in der Übersetzerausbildung an der Universität Pompeu Fabra", en Germanistentreffen Deutschland-Spanien-Portugal 13: 81- 89. Hallstadt: Rosch Buch, DAAD.

Hansen, G. (1998). "Die Rolle der fremdsprachlichen Kompetenz" en Snell-Hornby, M./ Höning, H. G. /Kussmaul, P./ Schmitt, P. A. (eds.). Handbuch Translation: 341-343.

Hulstijn, Hollander and Greidanus (1996). "Incidental vocabulary learning by advanced foreign language students: the influence of marginal glosses, dictionary use, and reoccurrence of unknown words." The Modern Language Journal, 80: 327-339.

Hurtado Albir, A. (1994). "Un nuevo enfoque de la traducción en la didáctica de lenguas" en de Agustín (Ed.). Cuadernos del tiempo libre. Colección Expolingua. Traducción. Interpretación. Lenguaje. 67-89. 
Little, D. (1997). “Autonomy and self-access in second language learning: some fundamental issues in theory and practice" in MÜLLER-VERWEYEN, M. (Ed.): Neues Lernen, Selbstgesteuert, Autonom. 33- 44.

Lockhart,W.F. (1993). "Estrategias de comunicación, estrategias de aprendizaje y transferencia de vocabulario pasivo a activo" in BRUTON,A./SIBÓN,T.G./ MANCHÓN, R.M.(Eds.). Serie sobre estrategias de aprendizaje y el uso del lenguaje. 21-30.

Krashen, S. (1977) "The Monitor Model for Second Language Performance" in Dulay, B. \& Finocchiaro (eds.) Viewpoints on English as a Second Language. New York. Regents. Translated on Liceras, J. M. (1992). La adquisición de lenguas extranjeras: hacia un modelo de análisis de la interlengua. Madrid: Visor.

Meara, P. (2007). "Simulating Word Associations in an L2: The Effects of Structural Complexity", Language Forum: A Journal of Language \& Literature. Vol. 33, $\mathrm{n}^{\circ} 2$, Jul-Dec 2007. 1331. New Delhi (India): Bahri Publications.

Möller Runge, J. (2001). Siglo XXI: ¿Innovamos? Enseñanza de una segunda lengua extranjera. Salobreña (Granada): Editorial Alhulia.

Nation, P. (2007). "Vocabulary learning through Experience Tasks", Language Forum: A Journal of Language \& Literature. Vol. 33, $n^{\circ}$ 2: 33-43. New Delhi (India): Bahri Publications.

Qian, D. (2002). "Investigating the relationship between vocabulary knowledge and academic Reading performance: An assessment perspective", Language Learning, 52/3: 513-536.

Solé, I. (1992). Estrategias de lectura, Colección MIE. Barcelona: Edit. Graó.

Valero Garcés, C. (1996). "L1 y L2 en el aula de idiomas: la lengua materna como complemento metodológico en la enseñanza de segundas lenguas" en BABEL-AFIAL 3-4-5: 187-197.

\section{ApPENDix}

\section{Fijate en la foto y contesta a las siguientes preguntas: / Look at the picture and answer the} following questions:

○ 1.1. ¿Qué te sugieren los colores pintados en las caras de los muñecos?/ What do you think about the colours painted on the faces of the puppets?

O 1.2. ¿Los relacionas con algo? /Do you see a connection with anything else? What?

○ 1.3. ¿Son jóvenes los chicos que aparecen en la foto? ¿por qué lo sabes? / Are they young? Why do you think so?

O 1.4. ¿Hablan los dos la misma lengua? ¿Qué idioma(s) hablan? Razona tu respuesta. / Do you think they speak the same language? Why or why not? What language(s) do they speak? Justify your answer.

○ 1.5. Anota todo aquello de lo que creas que puede tratar el texto que acompaña a esta foto. / Write down everything you think this text is about.

Figure 1. 


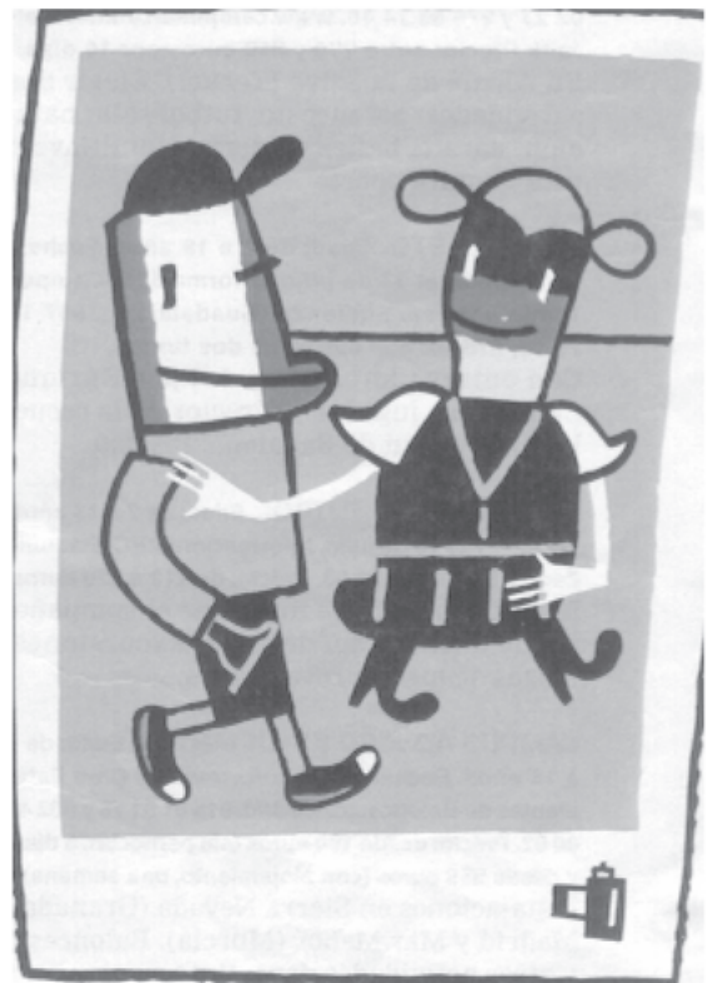

Figure 2.

\section{Cursos de idiomas}

Dominar otra lengua

Figure 3. 


\section{Cursos de idiomas Dominar otra lengua}

A CORUNA. Edad: de 11 a 16 años. Fechas: julio. Información: Forenex. Miguel Angel, 6, 2* 5. 28010 Madrid. 9130841 99. www.forenex.com. Precio: 600 euros (externos) y 1.100 euros (internos).

Cuatro horas de inglés diarias. Programa multideporte: hipica, golf, tenis y vela. Pis. cina, informática, polideportivo

ALEMANIA. Edad: de 12 a 17 años. Fechas: julio y agosto. Información: Linguatur. Leopoldo Alas Clarin, 16. 49018 Zamora. 9805110 87. Precio: de 772 a 1.565 euros.

En Augsburg. Programa multisport: con cuatro tardes semanales de tenis, voleibol baloncesto, badminton. squash o piscina.

AVILA. Edad: de 6 a 17 anos. Fechas: julio. Información: The Canadian Center. Sancho Davila, 10. 05420 Sotillo de la Adrada (Avila). 9186010 07 y 666450400 . www.thecanadiancenter.com. Precio: 520 euros por quincena.

En Piedralaves. Tenis, judo, hockey, esgri. ma, escalada, tiro con arco, croquet, 15 cla. ses de inglés a la semana
AUSTRALIA. Edad: de 14 a 17 afos. Fechas: julio y agosto. Información: Broadwater Educa tion Centre. Madrid. 913524558 y 913523760 Precio: 1.550 euros un mes.

Intercambio. Los españoles viajan en julio y vuelven en septiembre. Ios australianos vienen a Espana en enero y febrero.

BARCELONA. Edad: de 7 a 14 años. Fechas: julio. Información: King's College. 934545166. www.kingsinternational.es. Precio: 849 euros dos semanas.

En Calafell y L'Aldric. 15 clases de inglés por semana. Deportes de plava, bádminton. orientación. Talleres de artesania. Dia en Port Aventura.

BÉLGICA. Edad: de 10 a 18 an̂os. Fechas: julio y agosto. Información: Astex. Guecho (Vizcaya). 944608165 y 9021020 01. www.astex.es. Precio: 2.115 euros por dos semanas.

Inmersión total en inglés, francés o ale. man. Se realizan visitas culturales durante los fines de semana.

Figure $4^{8}$.

- Después de esta primera lectura intenta contestar a las siguientes preguntas: / After the first reading, try to answer the following questions:

o ¿Qué tipo de texto crees que es? / What kind of text do you think is it?

o ¿Quién podría ser el emisor del texto? / Who could be the emitter of the text?

$o$ ¿Dónde puede aparecer este texto? / Where can you see this text?

$o$ ¿A quién va dirigido? / What audience does it target?

o ¿Cuál crees que es el objetivo principal de este texto? / What do you think is the main objective of this text?

- Amplía la información del ejercicio anterior y después contesta a las siguientes preguntas: / Expand on the information from the above exercise and then answer the following questions:

o ¿Qué tipo de cursos se ofrece? ¿Ofrecen todos lo mismo? ¿Qué más ofrecen? Justifica tu respuesta / What types of courses are offered? Do they all offer the same thing? What else do they offer? Justify your answer.

o ¿Qué información se especifica en las palabras en mayúscula? /What kind of information do the words written in capital letters contain?

o Con respecto a la negrita, ¿qué tipo de información se engloba en ella? / What kind of information is found in the words in bold?

8. "Niños, propuestas para unas vacaciones animadas: 04 Cursos de idiomas. Dominar otra lengua", in Estilo de Vida de EP[S] El País Semanal número 1389: 85, Domingo 11 de Mayo de 2003. 
o ¿A quién van dirigidos los cursos? / For whom are the courses meant?

o ¿En qué época del año se ofrecen? ¿Por qué lo sabes? / When are the courses offered? How do you know?

o Independientemente de que sepas lo que significa exactamente, ¿qué duración tienen los cursos? ¿tienen todos la misma duración? / Without taking into account what you already know, how long do the courses last? Do they all last the same amount of time? 